\title{
LEAN TOOLS APPLIED IN TRANSPORT AND LOGISTICS SERVICES
}

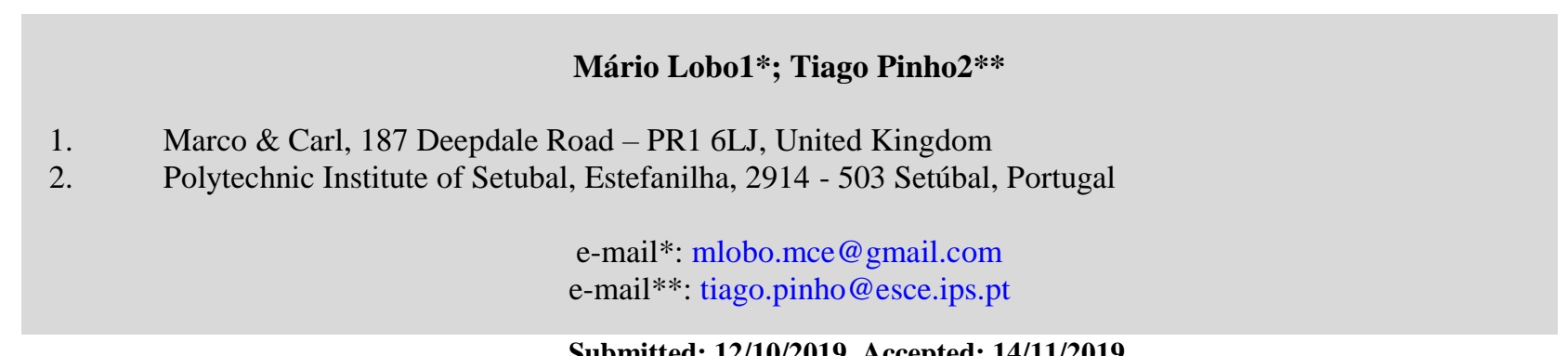

Submitted: 12/10/2019. Accepted: 14/11/2019

Published: 15/11/2019

\begin{abstract}
Purpose: This article is focused on the premise that applying Lean tools in transport and logistic services can contribute to reduce the costs, stocks, lead time and simultaneously contributing to major financial achievements. The objective is to create a model that allows the analysis and deployment of a Lean project in Logistic and Transport services.

Methodology: Facing the lack of information about the deployment and the results of the Lean tools in Logistic and transport services in Portugal we used as case study one example of a Portuguese company that deployed Lean tools on their services and it will show that the tools and Lean principles can be used to improve quality and efficiency by using the company existing resources, reducing causalities in the service provided and in all logistic process.
\end{abstract}

Findings: Lean tools provide efficiency in the services, allowing the increasing of the existing capacity in the company, provide a continuous improvement process. Even with low investments sustaining Lean projects can produce large improvement in efficiency of the processes and in the company profits.

Research Limitation: The data available about the subject in Portugal was the major limitation to the study.

Originality/Value of paper: To support the premise, will be provided a case study of a company that applied Lean tools into their services, areas inside the scope of the project and limitations of the services provided to their customers, how they deployed their Lean project and the results achieved.

KEYWORDS: Lean, 5S, Kanban, Poka-Yoke, Jidoka, Kaizen.

\section{FERRAMENTAS LEAN APLICADAS AOS SERVIÇOS DE TRANSPORTE \& LOGÍSTICA}

\section{RESUMO}

Proposta: Este artigo foca-se na premissa em que aplicando as ferramentas Lean nos serviços de Logística e Transporte, pode contribuir para uma redução de stocks, do tempo de espera e simultaneamente contribuir para melhores resultados financeiros. O objetivo será de criar um modelo que permita a análise e a implementação de um projeto Lean nos serviços de Logística e Transporte.

Metodologia: Face à falta de informação sobre a aplicação de projetos Lean em serviços de Logística e Transporte em Portugal, recorreu-se ao estudo de caso de uma empresa portuguesa que implementou um projeto Lean nos seus serviços e os resultados demonstram que as ferramentas e princípios Lean podem ser usados para melhorar a qualidade e a eficiência usando os recursos existentes na empresa, reduzindo as incidências nos serviços prestados e em todo o processo logístico.

Achados: As ferramentas Lean contribuem para aumentar a eficiência nos serviços, permitindo o aumento da capacidade da empresa, permitem e incentivam a melhoria contínua nos processos. Mesmo sendo suportados com baixo investimento os projetos Lean podem produzir grandes melhorias na eficiência dos processos e nos lucros da empresa.

Limitações da Pesquisa: Os dados disponíveis sobre este assunto foi a principal limitação do estudo.

Originality/Value of paper: Será apresentado um caso de estudo de uma empresa que aplicou as ferramentas Lean nos seus serviços, as áreas onde se focou o projeto e as limitações nos serviços prestados, como o projeto foi executado e os resultados alcançados.

PALAVRAS-CHAVE: Lean, 5S, Kanban, Poka-Yoke, Jidoka, Kaizen. 


\section{INTRODUCTION}

Running small Lean projects in transport and logistic services (Garza-Reyes et al., 2016; Kawa et al., 2019) can induce major improvements in quality (Kuvvetli and Firuzan, 2019), reducing cost of operations and reducing lead time (SARAVANAN et al., 2018). Lean tools help to face the dilemma of improving quality, reducing cost and lead time, meeting the customer demands and providing high quality services (NAINAAR and MASSON, 2018; PONTE et al., 2018).

Lean method is a systematic effort to reduce waste and cost (Saieg et al., 2018; Psomas et al., 2018), while simultaneously improve and standardize procedures (Gonzalez, 2019) in order to achieve high quality levels and financial incomes (BAKRI, 2019). To achieve the goals, this method takes us on an internal journey in the company and the different logistic departments, looking their inside and, then, improves procedures to use their resources efficiently.

The example of a Portuguese Company that deployed Lean tools on their services will show that the tools and Lean principles can be used to improve efficiency by using the company resources, reducing causalities in production line and during all logistic process.

Lean is a theme that has not been sufficiently explored in Portugal (Requeijo et al., 2018; Costa et al., 2019; Bittencourt, 2019) and even less known in logistic and transport services, therefore is the object of the present paper. So, this project is a result of a systematic data gathering about Lean theme and the way that he can be implemented in service companies, mainly connected to logistic and transport services. Lean is considered a method that can "produce fast quality", but it can induce in false interpretations such as the faster we go, more mistakes can be made. Lean doesn't focus only after the labor or the machines but reducing times and reducing the waiting time between activities and eliminating non-valued-added processes. Lean tools can also be used in services since the focus of his tools is to improve the speed and the quality in a process and can be deployed as a real contribution in any kind of companies including finance, Marketing, Sales, and Human Resources.

In addition to this introduction, this article presents a Methodology section. The following is a review of literature about Lean and its tools. Finally, the case study and the conclusions.

\section{METHODOLOGY}

The present article objective is to provide a model that allows the analysis and the deployment of a Lean project in logistic and transport services. Facing this theme, the methodologic methods chosen were the qualitative methods where the focus of the study is the understanding of the phenomena and their essence. When studying the deployment of a Lean project in Logistic and Transport services one obstacle emerged and it was the lack of data about the theme, therefore the strategy followed was the case study. On this case study the investigator (authors) don't have any control about the sequence of events or the results, the focus was on the phenomena (Lean project) running on a real and live context, collecting the data of the decision making process, how the decisions are taken, how they were deployed and what was the final result.

\section{LITERATURE REVIEW}

\subsection{LEAN}

Lean principles had their origin in Toyota and they were initially implemented by Taiichi Ohno on the fifties, just after the Second World War, where the natural resources were limited and Toyota was near bankruptcy due to the lack of investment and raw materials. Lean as we know, has derived of many evolution steps within Toyota Production System (TPS) and as a result focus all 
efforts in adding value to the customer and reducing waste. Lean has his origins in TPS, therefore follows four basic rules that provide all the strength:

1. All activities are focused on their content and at the final goal, with a timing and logic sequence:

2. All connections/relations between supplier and consumer must be direct:

3. The flux of the products and services involved must be simple and direct: Sensei.

4. All improvement occurs according to scientific methods and under the supervision of a

Lean adapted TPS basic rules and consider that all activities are properly defined and sustained, otherwise they can create factors of variation, or factors that consume time, efforts, money, raw materials and ultimately produce waste in the company. Such variations can hide or can be the cause of risk factors that can compromise the relationship between the work and the cost involved. These factors of variation induce negatives impacts in an organization, such as, low productivity of human resources, low quality of the final product or the service provided and, as final result, high costs (Spear \& Bowen, 1999).

Following the origins on TPS and keeping the focus on building the structure for the creation of a Lean concept, Fugio Cho during his presidency as Chairman of Toyota Motor Corporation, has created a metaphoric model that describes the concept and was baptized as The House of Lean:

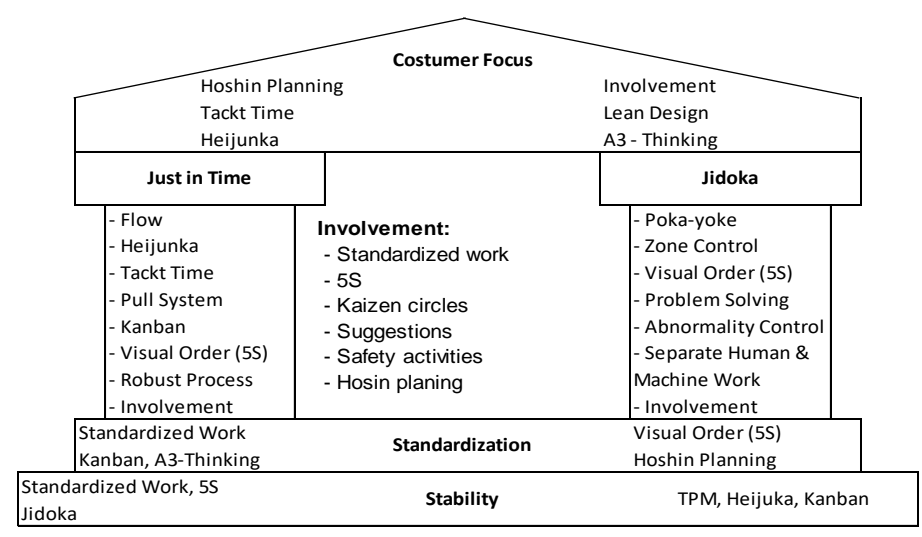

Figure 1 - The House of Lean (Dennis \& Shook, 2007)

\subsection{LEAN TOOLS}

There are several tools associated with Lean, namely, Jidoka, Poka-Yoke, 5S, Just in Time, Kaizen, amongst others.

\subsubsection{JIDOKA}

Jidoka, which in English means automation, was created in Toyota and, is a way to provide one operator or a machine the ability to stop the production process every time that any defect or something abnormal appears while the product or service is processed. This concept was introduced by Ohno T. (1988), facilitating the work of one person to operate more than one machine simultaneously, increasing the efficiency of the production. Jidoka term used to describe this process is pre-automation (Shingo S. 1981), that consists on the ability of a machine to 
automatically stop the production or a process when the quantity that was programmed is reached or when any activity or defect appears during the process.

Costs that don't add value must be eradicated, so Lean has a crucial part in the elimination of this costs.

\subsubsection{POKA-YOKE}

According to the same pillar, the equipment's or the systems should have mechanisms to detect defects and that lead to the detection and eradication of errors. These mechanisms are known as Poka Yoke and one worker must be responsible for multiple equipment's and operations, therefore he must process the ability to stop the process once that something not normal appears in the process, or when a problem emerges (Liker \& Hoseus, 2008). The use of flaw-proof devices (Poka-Yoke) induces the process control during all production activities. These devices only make sense to use when the $100 \%$ inspection into the process. This way, once a problem appears at the root of the problem is inspected, the process is stopped (Poka-Yoke), figure 2, feedback is provided and immediate actions are taken.

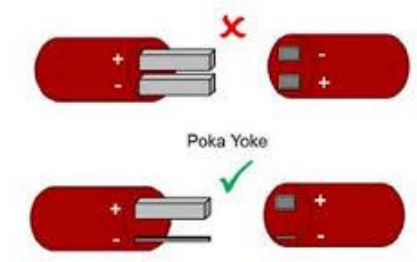

Figure 2 - Poka-Yoke System (MYLEANFACTORY, 2016)

\subsubsection{S}

5S was also created in Japan, after the Second World War (Silva, 2009) and is focused on the organization of the workplace, standardizing working processes and combining efforts to make work more efficient by eliminating obsolete instruments and materials, identifying materials, constantly cleaning the workplace and building a work environment that provides both physical and mental health, providing as well the will to keep the order in the place and to build the continuous improving motivation.

This is a profound philosophy but based on basic practices, providing and promoting one continuous growing of people work culture and the continuous improvement habits on the organization (Silva, 2009). 5S is based on goals to promote quality, promoting changes on people behaviour, simplifying the work environment, reducing waste, eliminating activities that don't add value, increasing safety and obtaining higher levels of efficiency and quality levels (Silva, 2009).

The costs involving all the $5 \mathrm{~S}$ process are so low that might be considered as one small investment that can create or provide great benefits (Sacristán, 2005). 5S is based on five principles:

1. Seiri - classify and organize any kind of materials according to its nature;

2. Seiton - keeping the place tidy is indispensable to keep the place organized, to organize the materials, optimize the space, providing better access and to contribute to increase efficiency;

3. Seiso - during the cleaning actions emerge opportunities to detect abnormal behaviors on the machines, instruments or any kind of equipment's or technologies;

4. Seiketsu - to standardize or to create standards on the ways of doing things, we need to develop systems that keep the place organized and that keep monitoring the process continuously. 
5. Shitsuke - to sustain or keep the changes we need to induce the ability and the discipline to do things right as they should be done.

Figure 3 shows $5 \mathrm{~S}$ deployment needs to get all the activities involving the processes simplified at their most basic level so they can provide strength to build and maintain the quality process and quality levels. The main phases are linked with by the cycle PDCA (Plan, Do, Check and Act) where there is not important if they are a phase of the model or if they appear explicitly to the workers (Lapa, 1998), but they know from the beginning that is the right way to work and the best way to achieve and maintain high levels of quality.

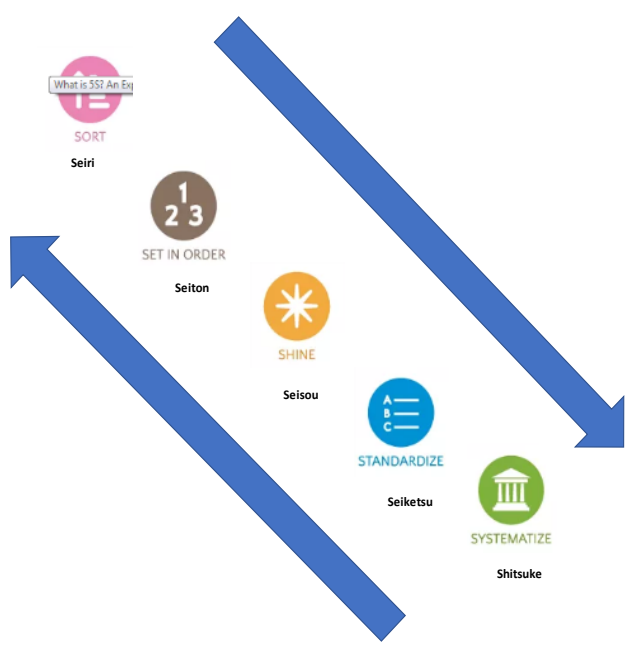

Figure 3 - 5S Method

\subsubsection{JUST IN TIME}

There were detected three kind of problems that should be fixed so the industry can be more competitive (Sugimori, Kusunoki, Cho \& Uchikawa, 1977):

The automotive industry was focused in mass production, based on assembly lines where each vehicle produced needed several thousand of elements, therefore incorporating a large number of processes.

Each automotive company had a large scale of models and each model with a large range of combinations of the components and extras that change according to the demand of the models;

All car models are remodeled and the components suffer the same alteration.

Just In Time (JIT) emerges to avoid problems with inventory and helps to build a culture of correct use of resources. JIT is a tool that allows the creation of production processes that reduces the lead time since the source of the raw materials or since the materials are being processed and place an order at the warehouse until the moment that a vehicle is ready to be delivered.

\subsubsection{KANBAN}

Kanban emerges as a mechanism to highlight each operation inside a process so, when the process needs to be supplied, it sends a message to the predecessor process (Liker \& Hoseus, 2008). This production control tool is also used to make sure that the manpower is used at full potential by:

1. Reduces the cost of data processing; 
2. Get to the facts fast and precise;

3. Set limits to the capacity of all predecessor activities.

Using a Kanban system, the predecessor processes are asked to supply after the components are already in use, turning more reliable the production and avoids the excess of production. Kanban means a label or card and it represents one document that contains all the instructions to assemble one item. This way the predecessor process is linked and works like the shelf and the final costumer as the next process. Kanban system allows each station to avoid flaws or excess of materials, search for polyvalent labor, stimulate the continuous improvement processes and the reduction of waste.

\subsubsection{KAISEN}

Kaizen is an improvement process no matter the process dimension or size that always goes in the direction of Lean goals or in other words, the elimination of waste (Ortiz, 2006). Kaizen is also used because one of the main concerns is the improvement of problem-solving, describing the process and process improvement, collecting and data analysis (Liker \& Hoseus, 2008). Usually, the improvement reached with Kaizen is a result of small and subtle changes but the final result is usually lasting and with a growing importance as time goes by. Kaizen is not limited to error eradication but has the important task to locate the root of the problem (Ortiz, 2006).

\subsection{INSIDE THE HOUSE}

The value created through Lean must be defined in terms of specific products or services, with their own specification, price or cost for specific clients (Womack \& Jones, 2003), the concept is always determined by the costumers, according to their particular needs, expectations and conditions of access to a particular product or service, with his own price and timeframe. So, each activity adds value to a process and at the end that added value must be recognizable and identified by the customer. Only after knowing all the flux of inputs and outputs of added value in the process we can dedicate time into waste elimination. Only through the study and development of the following items, figure 4 , it's possible to create value:

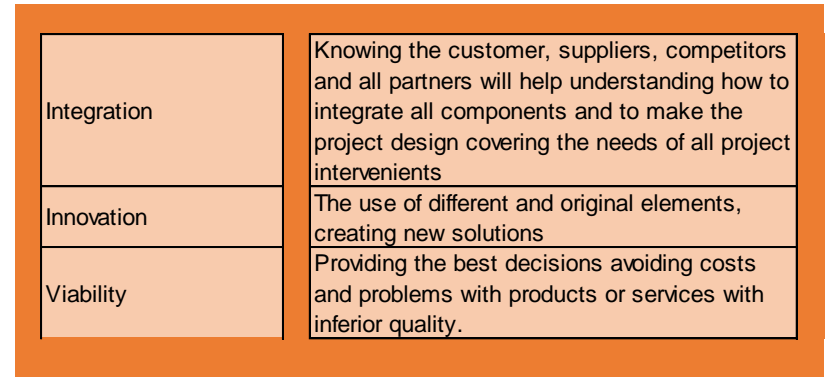

Figure 4 - Value Creation (Padilla \& Pekmezci, 2011)

With the objective of knowing Lean philosophy, figure 5, we need to know the 7 kinds of waste: 


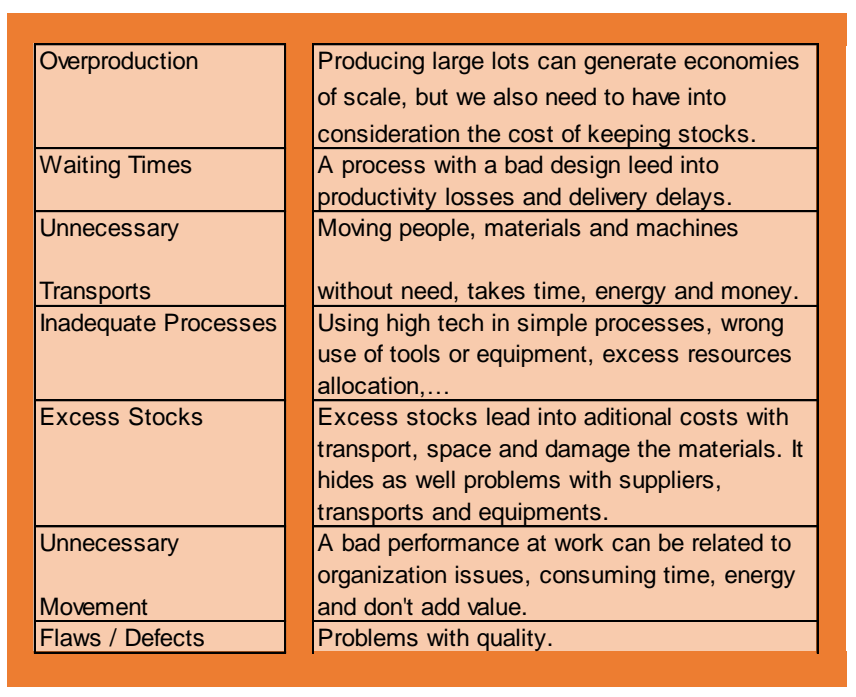

Figure 5 - Lean Seven Kind of Waste (TOYOTACOMPANY, 2007)

Initially there were only seven kind of waste and it was needed to include one new source, figure 6, of waste related with the inefficient use of Labor (Bellgran \& Säfsten, 2009):

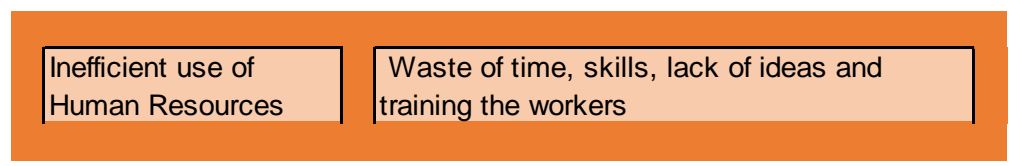

Figure 6 - Inefficient use of Human Resources (Bellgran \& Säfsten, 2009)

When the use of this method spread into other industries, figure 7 , including industries related with services, there where added six more kind of waste to the list (Bellgran \& Säfsten, 2009):

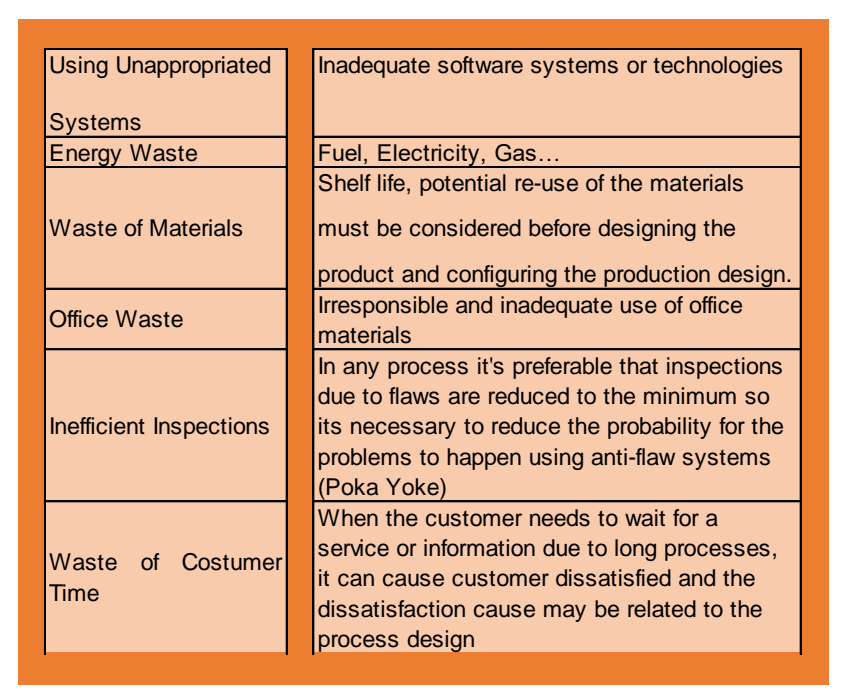

Figure 7 - Waste from Services Industries (Bellgran \& Säfsten, 2009) 
The Lean tools are designed to maintain the involvement of the team on activities that can reduce waste and add value to the final product or service.

\section{CASE STUDY - LEAN TOOLS IN TRANSPORT AND LOGISTICS SERVICES}

Transport and Logistic companies are facing new challenges and restrictions that require attention, financial efforts, methods and techniques that can help to place this companies in the line of efficiency, reducing costs and al redundancies that affect directly the financial and quality results.

In transport and logistic services if we ask to a group of 20 individuals from different companies how they perform their job describing their tasks step by step, the probability to have the same answer is very slim, probably we end of with 20 different descriptions about the same job. Therefore, we raise a question: How can we improve a process that is built by twenty processes? Or, how can we improve something that doesn't exist?

Combining these twenty processes we will compose a better process for everyone, a process that can make every task consistent and produce better results, using less time and reducing waste. The lack of standards and well documented processes is one of the reasons that improving processes in transport and logistic services can be a big challenge. Filling up the gaps becomes a critical issue because it can induce the variation reduction and waste leading to significant earnings in quality, time and financial.

Combining Lean tools in transport and logistic services will improve the processes, financial incomes and will contribute to continuous improvement.

\subsection{DEPLOYNG LEAN PROJECTS IN LOGISTIC AND TRANSPORT COMPANIES}

Before deploying Lean projects in transport and logistic services, the companies should adapt and create a model that can provide an answer to their needs. Inside transport and logistic services there are some options where adapting this model can work:

\subsubsection{BE CREATIVE WHEN SETTING UP THE DATES FOR PROJECT MEETINGS}

Looking inside the transport and logistic services company that supported the case study, when we decompose the transport service and look at the beginning, it's always someone from the traffic department that start the service by accepting the job. Then the executive chief of traffic control of the company needs to plan all daily schedule and places to go for every driver, times and places. After, when the driver is on his way back, it's important to define the loading times on the customer, so the service can be profitable. After creating all the schedules, the team must inform the driver when and where the cargo should be unloaded or loaded and the precise times along the driver daily route. In this particular case, the most important is for the vehicle to leave the dock full, perform all unloading activities and return to the warehouse with the vehicle full of cargo to be delivered on the next day, all over the country.

All staff involved opted to have the brainstorm meetings on the end of the day to provide all data about the exact places of unloading and loading of the day, the conditions and restrictions they had, so that on the next delivery or pickup, in the same place, the driver and the car should be ready to face all obstacles. After considering all data, where identified some restrictions that should be taken under consideration: 
- $\quad$ The drivers legal schedule, 8 hours driving and 15 hours on the working day to finish the service during the day or 8 hours driving and 10 hours on the working day to finish the service during the night.

- $\quad$ The loading and unloading timeframes on the big retailer's logistic centers.

- The loading or unloading places with timeframes after the retailer's service.

- $\quad$ All the rest of the deliveries and pickups on time to get back on the base without extra hours.

This was the exact starting point for all the discussions and it took a few days to reach one agreement because each and every day new obstacles arisen and new opinions to solve the problem where presented to the group so the process could be improved. So, on the end of the first week the meetings where ended with a list of all the points that the project should take in consideration such as:

- The way that the vehicle is loaded - the cargo must be properly placed and secured.

- The cargo must be placed in order of unloading, or at least "almost" in order of unloading. The "almost" was taken in consideration when one pallet is too high and the next too small, so the cargo will not be secured and fall down.

- $\quad$ Beginning the loading operations in early morning, making the drivers move all cargo loaded in all following unloading places, losing precious time.

- $\quad$ The office providing help to find the final unloading places and contact the final destinations so they can be ready to unload the vehicle.

- The information must flow both ways between the traffic department and the drivers and also between all drivers that are at the same road so they can inform the colleagues about the traffic conditions or the final places of loading or unloading.

This informal meetings brought into the table options for improvement that where ultimately tested on their day-to day activities so the improvement proposals can be properly tested and taken as normal way to do the job by all the team and at the same time leaving some room for improvement or activities that can contribute for continuous improvement. All these activities can lead into better financial results, reduction on time wasted, effort, fuel, electricity..., and at the same time providing a top service and fulfilling the customer needs. All meetings and extra work hours dedicated to this project, were rewarded by the simple fact that the drivers are actually working less hours and with less effort.

\subsubsection{LOOK FOR OPPORTUNITIES THAT CAN PROVIDE FAST RESULTS}

It was decided from the beginning to start the first small project on the Third Party Logistic (3PL) warehouse. All involved staff had identified actions that could improve processes and reduce accidents and incidents with the pallets inside the warehouse. So, it was only needed to set a few new rules to do the service as the way that the pallets are unloaded from the truck to the warehouse.

Initially, all pallets where unloaded to one particular place at the warehouse so the truck could be unloaded as soon as possible so that could leave the dock as soon as possible. The problem was that all pallet references where mixed and the time spent to check all pallets was too much, the truck and the driver where in fact in a short period of time at the dock but then, they were waiting for the time that the staff was checking the goods in to the warehouse, the quantity, grouping them by batch, checking pallets for damages and, finally signing in the goods. After that, 
the driver was released and then, the staff started to move the pallets to the 3PL warehouse and in racks according with the batch number.

Immediately they had recognized that this process was full of waste so they analysed and mapped the process starting with a simple rule, Unload - Check Properly - Place according Batch and then, everything was placed on the 3PL warehouse. If some of the pallets had one problem, the customer was immediately informed and photos where provided. At the end of 3 weeks, 50\% of the time was reduced by cutting non-value -activities. All the time that the driver spent waiting to be released was also reduced in $60 \%$.

\subsubsection{INCLUDING KAIZEN TO ACCELARATE THE PROCESS}

Deploying Kaizen improvement processes on 3PL services, all actions involved a specific and intensive work on all improvement actions, mainly due to the time that staff dedicate to the project usually ended on the end of the project hours. During the rest of the hours, the staff was involved in another project to change the layout of the warehouse and the racks, providing more storage space on the 3PL warehouse and at the same time, providing space for the operations warehouse and also reducing the time spent on operations warehouse. All this improvement had also affected the problems, accidents and incidences with the pallets in more than $50 \%$, increasing the customer satisfaction and reducing the loss.

This model was designed in working hours and without any kind of interference of the management and after the first week, the management team and all board of directors where amazed by the results achieved and both the enthusiasm carried by all people involved in the process. They all had seen the quick results, and the fact that they were having less problems and less extra hours.

This was a big win for the team, but there were other situations that it was very difficult to pull out the staff from their own "normal" activities to look at the processes, study and establish a plan for improvement. Even though and facing this situation, the staff started new ways to adapt and face the day-to-day problems and adapt to the new challenges and at the end, they had achieved extraordinary results. All kaizen tools adapted worked due to:

- $\quad$ They are based on people knowledge, the same people that do the work.

- $\quad$ They use data collected on the decision-making process.

- All begins with a small description of the problem or an opportunity ready to be placed in action.

- Verifying the goals each and every step of the way so these goals can be measured.

\subsubsection{TRY TO GO FURTHER THAN THE LIMITS OF THE TEAM EVERY TIME YOU CAN}

When the staff conceived and presented a draft to improve the layout of the warehouses, a short while after they started to map and to study the process, it was created a new group that involved drivers, traffic department, cross-docking, warehouse operations and, 3PL staff and management where:

- Drivers - they had put on the table all their concerns with the time spent loading, unloading and the way that the cargo was placed on the vehicle. 
- Traffic Department - they were worried with the flow moving the pallets and the general cargo at the warehouse, and the amount of time that the vehicles were on the dock.

- Warehouse Operations - they were worried with the space they had to move all the cargo, receiving and expediting, checking and storing in the minimum time possible and without incidents/accidents.

- 3PL Staff - worried the way that the cargo was received, checked, moved on the warehouse, stored and dispatched without accidents or incidents.

- Management and Administrative Services - worried with data flowing from the warehouses to the office, from the office to the costumers and, at the end, to keep the customer happy.

\subsubsection{ESTABLISH REALISTIC GOALS}

All the actions connected to the project and initially deployed in the company had has an initial common goal to map and describe all processes and, after knowing the processes they could chose the ones to be targeted by Lean small projects and then, they developed improvement actions that could provide fast results and better fit the team.

In the beginning, it was difficult to start, no one wanted to spend more time at the company or "loose" time to be involved on the projects, a few staff members were "forced" to be a part of the first Lean Team, so, for the leaders of these projects the pressure was very high but, after the two weeks work and the first Lean small project finished (3PL), all teams and departments saw the results, and then all staff was eager to be a part of a project and started to give new ideas for new Lean small projects.

In the end, all of these Lean small projects got positive results, some of them even exceeded the expectations keeping all staff and the administration eager to be involved in future projects.

\subsubsection{BE CAREFUL COMPOSING THE TEAM}

One of the problems that the first Lean team leaders found was the available that the staff had to be involved in the project, so it was a challenge to build a team that could be involved in the project, do the daily activities and deliver results. Initially, some of the staff members felt "forced" to belong in the team because they were the head of the departments or persons that their job makes them as a mandatory presence in the project because they were the ones that knew the project from the beginning until the end, so to identify and define the processes they were not replaceable. Even "forced" to be a part of the first Lean project, soon enough, the same persons where the key for the success, the first motivators to find new ways to improve the process and they kept on working the new ways of doing things.

On a second phase and still facing the success of the first Lean small project and the impact that all improvement actions had on the company branch, the staff got involved and made a personal effort to be a part of the next Lean small projects teams. That was a real turnover for the team leaders, the staff moved from "forced" to dispute a membership on the next small Lean project or creating brainstorm sessions to find new ideas, new ways to improve the service. ' 


\subsection{THE ORIGIN OF WASTE AND THE NEED OF LEAN TOOLS}

In services related companies there are a few reasons why their departments and the services they provide need Lean tools:

- These services processes are slow, expensive and with low quality. They affect the costs, causing them to grow, creating non satisfied customers and compromising the company revenues.

- The processes are slow because they have too many work-in-progress (WIP), the origin of this WIP can be the reports stuck in a desk waiting for one approval, e-mails in the mailbox waiting to be taken care of, or sales pending because they are waiting for a simple Ok. When we have to much WIP, the effective work can be on hold around $90 \%$ of the time a fact that is not helping the customers satisfaction and injects costs on the process.

- In any slow process, $80 \%$ of the delay is caused by less than $20 \%$ of the activities related to the process. So, we need to focus in $20 \%$ of the steps or activities of the process to gain time on the cycle reducing it by $80 \%$ and raising the percentage of the on-time deliveries.

Lean when applied to service companies is based on a fast way to get results and these results can be seen from the beginning until the end of the process, supporting the strategic goals related to the project.

Before starting one Lean project, we need to make shore that all staff from all departments is involved on the project and working with the same goals, avoiding barriers to implement the project, making the improvements a day-to-day activity and contributing to a continuous improvement environment.

\subsection{CHALLENGES IN LOGISTIC AND TRASNPORT SERVICES PROCESSES}

The way that the transport and logistic services work can set multiple difficulties identifying what should be changed and how it's going to be repaired. It's not easy to get in a warehouse office and see how the work flows, the way that al materials flow inside the warehouse until are finally despatched. So, in logistic and transport services the challenges to find and improve the processes can include:

- Track back the work flow, encouraging the team to be creative and to identify the part of the process they are currently working on;

- The individual work, where the staff member is generally told what to do, how to do and what the company expects from his work and he is left to his own luck, doing his own way the daily duties that the company expects from him. Therefore, the easiest way we have to make the staff accept all the changes on the process by involving them on the decision-making process.

- The lack of data to support decisions. We need to know the amount of work that is kept waiting on any time of the process. This work doesn't refer only on late deliveries, traffic, preparing the cargo on the warehouse, but all work supporting transport and logistic tasks. We need to know and keep on track the average time that spent on daily tasks, like phone calls, reports, orders...

- The processes connected with transport and logistic services are extremely dependent on human interaction. It's easier to reduce times in one equipment than to make a person related to traffic control of a transport company reduce the time of a phone call with a customer or a driver when he his receiving or transmitting instructions or when he is dealing and organising services requests from all over the country. We should consider all problems and difficulties with the staff 
in each and every step of the improvement deployment process, for that we need to involve the staff in a continuous improvement actions and turn this actions in day-to-day activities, supplying all training needed so they can understand the importance of the changing process.

These challenges can look a little frightening on the beginning but can contribute to improve the service process and at the same time to be gratifying to all people involved because they can put in action all their creativity. Since the results and the earnings with this kind of projects are fast, they can be seen by the staff and the staff can see all their contribute put in action into a common goal.

\subsection{Recognizing Waste in Transport and Logistic Services}

The greatest challenge when deploying Lean projects is in fact to be able to identify the waste and most of all, waste origins. Unfortunately, most of transport and logistic services the way of doing things are always the same and people tend to accept all kind of situations in an erratic or automatic way, walking around in every directions and simplifying only one little fraction how the work should be done. In transport and logistic projects part of Lean discipline consists in identifying the "7 Ways to Produce Waste", now adapted to transport and logistic services:

Waste 1 - Overpricing the Service - trying to give to a transport or a logistic service one value or price that the customers don't recognize or are not willing to pay for it:

1) This situation emerges when the company doesn't really know the customer needs and ends up to input more value that the customer is willing to pay for the service.

2) Allowing non-value-added activities inside of a process, turning al activities slower than they should be and increasing the working time inside of the process itself.

So facing this problem, the Lean team started to improve the processes and took actions that allowed reducing accidents and minimizing waste:

a) Including one person to help the driver in deliveries that need to be handled by hand.

b) The creation of specific prices to a specific service so the customer pays exactly for what he had the service contracted with the company.

c) Adjustment of the branch fleet according to the customer's needs and cargo destinations.

d) Adjusting the vehicles with equipment's to perform the job (pallet holder, GPS, trackers, scale).

Waste 2 - Unnecessary Movement of Products or Data - this is one of the biggest problems in this sector, because moving cargo more than we need means to spend more money with fuel, electricity, time, human recourses, machinery, the paperwork involved and increases the risk of accident while the cargo is moved from one place to the other.

Transport Service - we need to make shore from the beginning what we really to make the transport service, the conditions that the final destination have to handle the cargo, the roads (straight, traffic...), the unloading times, the roads that the driver can use, if the customer have space for the cargo, if is someone at the final destination to receive the goods... otherwise, the company needs to bring back the cargo, wasting fuel, time, driving time and space in the vehicle to the day's pickups. Once the traffic knows that the cargo is returning to the base, they need to perform an internal incident report, communicate the problem to the customer and to set up a new delivery date. Meanwhile, the cargo is coming back to the warehouse and the risk to have one 
incident increases because it's in the way of all the rest of the deliveries. Facing this problem, the Lean projects team took into action the following improvements:

a) Reducing distances with empty vehicles in $40 \%$ by finishing the deliveries near the first pickup.

b) GPS navigation and trackers to help the driver avoiding traffic and avoiding detours.

c) After the last delivery the vehicle only moves to go to the next pickup point.

d) Creating one office in the warehouse to avoid the drivers to go around the warehouse and the offices looking for documents or instructions.

e) Every time that is possible, the cargo is loaded on the vehicle according to the destinations. This rule is only broken when the size or the safety of the cargo don't allow to perform the service.

f) Confirming in advanced all conditions on the delivery places, avoiding the return of the cargo.

Logistic Service - the unnecessary movement of cargo leads us into a waste of human recourses time, materials, energy, and fuel creating serious delays on the service. When the process is not clear, it takes us to contract more cargo handlers and machinery. The risk of damaging the cargo increases every time the cargo is moved. Misplacing the cargo, loading on the wrong vehicle or even losing the cargo.

When the logistic services where analysed, the major improvement actions involved:

a) Reducing or terminating the unnecessary movement of cargo inside the warehouse.

b) Identifying and Placing the cargo if possible, always near the place of storage or dispatch.

c) Keep the driver updated of any changing in cargo manifest or destinations.

Waste 3 - Unnecessary Movement of People and Materials - Moving people or material refers to the situations that the staff need to change between programs, printers, offices to perform their job, moving around the building picking up documents or delivering documents without need for that. One of the solutions is to rearrange the office and the staff desks near the places or equipment's they need to be, avoiding waking around the office to get one printed paper from one printer that should be near the desk.

Facing this situation, the improvement actions involved:

a) Placing the equipment's near the users.

b) Adapting informatics tools making them easy for the final users.

c) Creating routines avoiding getting in and out constantly the programs.

d) Creating routines avoiding unnecessary walks around the office or warehouse.

Waste 4 - WIP that Exceed the Customer Needs- WIP can create waste, cost related while they are waiting to be used and causes long lead times, increasing the probability of the service don't match with what it's really needed. To avoid WIP that exceeds the customer needs, the following improvements were taken into action:

a) Creating logical working sequences.

b) Replacing and eliminating forms that don't add value to the process.

c) Analyse all pending cargo and pending requests.

d) Quick response reports to the traffic and costumers with cargo accidents or incidents. 
Waste 5 - Time Between the Beginning and the end of a Process and the Beginning of the Next Activity - in services, the amount of work between activities is almost invisible. The waiting times are a problem to transport and logistic companies, so we need to map the process to find delays and congestions. Mapping the process, we can see where the process is stopped and waiting for someone to do something. To reduce the waiting times, the improvements where focused in:

a) Creating loading and unloading booking times in the main warehouse.

b) Booking unloading times in final destinations.

c) At the end of the day, analyses everything that went wrong so the problem won't repeat.

Waste 6 - Any Aspect of the Service that doesn't Match to the Customer Needs - in transport and logistic companies delays, flaws or incidents can result on missing the delivery agreed time, lack of information passed to the driver,..., causing the customer to be not happy with the service and ultimately with the company. To improve this area Lean project focused in:

a) Giving clear written instructions to the drivers.

b) To be quick communicating accidents or incidents with a delivery to the traffic and to the customer.

c) Careful use of equipment's.

Waste 7 - Service Overproduction - The Work Involved is More than Necessary - Improving service overproduction involved actions that helped to:

a) Supply the service that the customer asked without using any other non-contracted tool except when it was helpful to the driver or the service itself.

b) Planning "exceptional" deliveries (due to the size, weight, the specific equipment's involved, unloading places...), the traffic should be informed in advanced off all accesses, unloading conditions so they can properly plan the delivery, avoiding the return of the cargo.

c) When it's necessary to bring back and deliver the same cargo on another day, this must be properly planned and the cost must be supported by the customer.

Overproduction causes service congestion with unnecessary non-value-added activities that the customer didn't ask or simply don't want, causing congestion on the internal services and waste. In the case of the transport, Lean team found and took action on the following:

a) When a customer wishes to get their POD's by e-mail, there is no need to print them out and sending them by mail, wasting time and money on post.

b) When they use one vehicle with help to unload one pallet in one place that have a fork lift, they were wasting one person only to travel, while he could be of better use elsewhere.

\section{CONCLUSIONS}

It is important to outline that all results achieved with the Small Lean Projects were the result off all team involvement on them, at first it was a little shy involvement and for some, "they were made to be a part of the project" but soon enough, everybody got involved and made their best to create and keep the results achieved. One "secret" of the success was the involvement of the owners and management team, they started the project as their own and made the first team, this way all company staff saw their will and personal involvement making it easier the improvement process and to keep the changing process. Without this personal involvement of the 
top management team all improvements, changing process and all results would be seriously compromised.

It's important to take into consideration the people that keep the process in action because they are the key for the changing process and all the improvement actions, their personal involvement will lead to better and faster results.

\subsection{SMALL LEAN PROJECTS IN LOGISTIC AND TRANSPORT SERVICES}

The constant and fast changes in transport and logistic services force the companies to pay attention to the market, to have a close relationship with the customers so, when the time comes, they can adapt to the changes and improve their services while fulfilling their needs and keeping the customers happy and improving financial results. There is no limit to the creativity or the service improvement, for example it's possible to place one cargo in all big distribution Hubs in 24 hours.

When applying Lean methodology and Lean Tools to transport and logistic services show that a systematic effort to detect, control and reduce waste and at the same time, reducing all cost involved in the process. At the same time, these tools are correcting and improving the processes, turning them into standard processes, allowing them to achieve high quality standards and improving financial results.

In the studied company the Small Lean Projects had reinforced the opinion of all authors quoted on this paper, since these projects brought to the company better quality and higher financial results and al the process improvement activities were kept in time and some of them where targeted in other projects to keep on the improvement process. The management team kept on the involvement on the changing process and the small projects, keeping all staff involved in the continuous improvement company actions.

All the achieved results kept the internal customers happy (Transports, Drivers, Warehouse, Cross-Docking, 3PL, Office...), keeping happy the company customers with the improvements on the services provided and reducing accidents, incidents and problems with the cargo. All these improvements had contributed to improve the company name and image in the market.

\subsection{MAIN RESULTS}

After the end of the project the main results achieved with the deployment of the Lean project in the company were:

- The efficiency has increased;

- Less frequent errors;

- Increase in load capacity (both on the cars and the warehouses);

- The work planning was improved;

- The global operation revealed increasing profits.

\subsection{PROJECT FINDINGS}

- The use of Lean tools in logistic and transport services allowed the increase of the existing capacity; 
- The data gathering allowed the continuous improvement process;

- Low investment Lean projects produced a large improvement in efficiency.

\section{REFERENCES}

BAKRI, M. Implementing Lean Tools to Streamline Banking Operations: A Case Study of a Small Lebanese Bank. Management Studies and Economic Systems, v. 4, n. 2, p. 131-144, 2019.

BELLGRAN, M.; SÄFSTEN, K. Production Development: Design and Operation of Production Systems. SpringerVerlag, 2009.

BITTENCOURT, V., SALDANHA, F., ALVES, A. C., LEÃO, C. P. Contributions of Lean Thinking Principles to Foster Industry 4.0 and Sustainable Development Goals. In: Lean Engineering for Global Development. Springer, Cham, p. 129-159, 2019.

COSTA, A. R., BARbosA, C., SANTOS, G., ALVES, M. R. Six Sigma: Main Metrics and R Based Software for Training Purposes and Practical Industrial Quality Control. Quality Innovation Prosperity, v. 23, n. 2, p. 83-100, 2019.

DENNIS, P.; SHOOK, J. Lean Production Simplified. 3rd Edition. Routledge, 2007.

GARZA-REYES, J. A.; VILLARREAL, B.; KUMAR, V.; \& MOLINA RUIZ, P. Lean and green in the transport and logistics sector-a case study of simultaneous deployment. Production Planning \& Control, v. 27, n. 15, p. 1221-1232, 2016.

GONZALEZ, M. E. Improving customer satisfaction of a healthcare facility: reading the customers' needs. Benchmarking: An International Journal, v. 26, n. 3, p. 854-870, 2019.

KAWA, A.; MARYNIAK, A. Lean and agile supply chains of e-commerce: empirical research. Journal of Information and Telecommunication, v. 3, n. 2, p. 235-247, 2019.

KUVVETLI, Ü.; FIRUZAN, A. R. Applying Six Sigma in urban public transportation to reduce traffic accidents involving municipality buses. Total Quality Management \& Business Excellence, v. 30, n. 1-2, p. 82-107, 2019.

LAPA, R. Os cinco sensos. In: http://www.ptnet.com.br/5sensos, 1998.

LIKER, J. K.; HOSEUS, M. A cultura Toyota. A alma do modelo Toyota. Porto Alegre: Bookman, 2008.

MYLEANFACTORY. Poka-Yoke System. In: https://www.myleanfactory.de/, 2016.

NAINAAR, D., MASSON, J. An Investigation into Technology Management to Create Sustainable Competitive Advantage Within the Fast Moving Consumer Goods (Fmcg) Beverage Industry. European Journal of Engineering and Technology, v. 6, n. 2, 2018.

OHNO, T. Toyota Production System: Beyond Large-Scale Production. New York: Productivity Press, 1988.

ORTIZ C. A. Kaizen Assembly: Designing, Constructing, and Managing a Lean Assembly Line. New York: CRC Press, 2006.

PADILLA, R.; PEKMEZCI, T. A Framework for Designing a Lean Production System for SMEs. MsC Thesis Work 2011, Jönköping University, Sweden, 2011.

PONTE, B., COSTAS, J., PUCHE, J., PINO, R., DE LA FUENTE, D. The value of lead time reduction and stabilization: A comparison between traditional and collaborative supply chains. Transportation Research Part E: Logistics and Transportation Review, v. 111, p. 165-185, 2018.

PSOMAS, Evangelos; ANTONY, Jiju; BOURANTA, Nancy. Assessing lean adoption in food SMEs: evidence from Greece. International Journal of Quality \& Reliability Management, v. 35, n. 1, p. 64-81, 2018.

REQUEIJO, J. F. G.; ABREU, A. J. P. DA C. F.; CALADO, J. M. F.; DIAS, A. S. M. DA E. SIX SIGMA BUSINESS SCORECARD APPROACH TO SUPPORT MAINTENANCE PROJECTS IN A COLLABORATIVE CONTEXT. Revista Produção e Desenvolvimento, v. 4, n. 1, p. 82-97, 2018.

SACRISTÁN, F. Las 5S: Orden y limpieza en el puesto de trabajo, FC Editorial, 2005.

SAIEG, P., SOTELINO, E. D., NASCIMENTO, D., CAIADO, R. G. G. Interactions of building information modeling, lean and sustainability on the architectural, engineering and construction industry: a systematic review. Journal of cleaner production, v. 174, p. 788-806, 2018. 
SARAVANAN, V.; NALLUSAMY, S.; BALAJI, K. Lead time reduction through execution of lean tool for productivity enhancement in small scale industries. International Journal of Engineering Research in Africa. Trans Tech Publications, p.116-127, 2018.

SHINGO, S. A Study of the Toyota Production System. Productivity Press, 1981.

SILVA, L. Gestão e Melhoria de Processos: Conceitos, técnicas e ferramentas. Brasport, 2009.

SPEAR, S.; BOWEN, H. K. Decoding the DNA of the Toyota production system. Harvard business review, v.77, n.5, p.96-106, 1999.

SUGIMORI, Y.; KUSUNOKI, K.; CHO, F.; UCHIKAWA, S. Toyota production system and kanban system materialization of just-in-time and respect-for-human system. The International Journal of Production Research, v. 15, n. 6, p. 553-564, 1977.

TOYOTACOMPANY. Lean Seven Kind of Waste. In: https://global.toyota/en/company/, 2007.

WOMACK, J.; JONES, D. Lean Thinking: Banish Waste and Create Wealth in Your Corporation. Journal of the Operational Research Society, v.48, n.11, 2003.

All authors stated that they had: a) actively participated in the discussion of the results; and b) Review and approval of the final version of the paper.

This work is licensed under a Creative Commons Attribution 4.0 International License. CC-BY 